\title{
Embryonic Stage of Congenital Zika Virus Infection Determines Fetal and Postnatal Outcomes in Mice
}

\author{
Eri Nakayama ${ }^{1, * \mathbb{D}}$, Yasuhiro Kawai ${ }^{2,+}$, Satoshi Taniguchi ${ }^{1,+}+\mathbb{D}$, Jessamine E. Hazlewood ${ }^{3,+} \mathbb{D}^{\text {, }}$ \\ Ken-ichi Shibasaki ${ }^{1}$, Kenta Takahashi ${ }^{4}$, Yuko Sato ${ }^{4}$, Bing Tang ${ }^{3}$, Kexin Yan ${ }^{3}$, Naoko Katsuta ${ }^{1}$, \\ Shigeru Tajima ${ }^{1} \mathbb{D}$, Chang Kweng Lim ${ }^{1}\left(\mathbb{D}\right.$, Tadaki Suzuki ${ }^{4}$, Andreas Suhrbier ${ }^{3} \mathbb{D}$ and Masayuki Saijo ${ }^{1} \mathbb{D}$
}

1 Department of Virology I, National Institute of Infectious Diseases, Tokyo 162-8640, Japan; rei-tani@nih.go.jp (S.T.); shi-k@nih.go.jp (K.-i.S.); nkatsuta@nih.go.jp (N.K.); stajima@nih.go.jp (S.T.); ck@nih.go.jp (C.K.L.); msaijo@nih.go.jp (M.S.)

2 Management Department of Biosafety and Laboratory Animal, Division of Biosafety Control and Research, National Institute of Infectious Diseases, Tokyo 162-8640, Japan; kaya@nih.go.jp

3 Inflammation Biology Group, QIMR Berghofer Medical Research Institute, Brisbane, QLD 4029, Australia; Jessamine.Hazlewood@qimrberghofer.edu.au (J.E.H.); Bing.Tang@qimrberghofer.edu.au (B.T.); Kexin.Yan@qimrberghofer.edu.au (K.Y.); Andreas.Suhrbier@qimrberghofer.edu.au (A.S.)

4 Department of Pathology, National Institute of Infectious Diseases, Tokyo 162-8640, Japan; tkenta@niid.go.jp (K.T.); kiyonaga@nih.go.jp (Y.S.); tksuzuki@niid.go.jp (T.S.)

* Correspondence: nakayama@nih.go.jp; Tel.: +81-3-5285-1111

+ These authors contributed equally to the work and should be considered as second authors.

\section{check for} updates

Citation: Nakayama, E.; Kawai, Y.; Taniguchi, S.; Hazlewood, J.E.; Shibasaki, K.-i.; Takahashi, K.; Sato, Y.; Tang, B.; Yan, K.; Katsuta, N.; et al. Embryonic Stage of Congenital Zika Virus Infection Determines Fetal and Postnatal Outcomes in Mice. Viruses 2021, 13, 1807. https://doi.org/ 10.3390/v13091807

Academic Editors: David Baud and Leó Pomar

Received: 30 July 2021

Accepted: 8 September 2021

Published: 11 September 2021

Publisher's Note: MDPI stays neutral with regard to jurisdictional claims in published maps and institutional affiliations.

Copyright: (c) 2021 by the authors. Licensee MDPI, Basel, Switzerland. This article is an open access article distributed under the terms and conditions of the Creative Commons Attribution (CC BY) license (https:/ / creativecommons.org/licenses/by/ $4.0 /)$.
Abstract: Zika virus (ZIKV) infection during pregnancy causes a wide spectrum of congenital abnormalities and postnatal developmental sequelae such as fetal loss, intrauterine growth restriction (IUGR), microcephaly, or motor and neurodevelopmental disorders. Here, we investigated whether a mouse pregnancy model recapitulated a wide range of symptoms after congenital ZIKV infection, and whether the embryonic age of congenital infection changed the fetal or postnatal outcomes. Infection with ZIKV strain PRVABC59 from embryonic day 6.5 (E6.5) to E8.5, corresponding to the mid-first trimester in humans, caused fetal death, fetal resorption, or severe IUGR, whereas infection from E9.5 to E14.5, corresponding to the late-first to second trimester in humans, caused stillbirth, neonatal death, microcephaly, and postnatal growth deficiency. Furthermore, 4-week-old offspring born to dams infected at E12.5 showed abnormalities in neuropsychiatric state, motor behavior, autonomic function, or reflex and sensory function. Thus, our model recapitulated the multiple symptoms seen in human cases, and the embryonic age of congenital infection was one of the determinant factors of offspring outcomes in mice. Furthermore, maternal neutralizing antibodies protected the offspring from neonatal death after congenital infection at E9.5, suggesting that neonatal death in our model could serve as criteria for screening of vaccine candidates.

Keywords: Zika virus; congenital Zika syndrome; SHIRPA; microcephaly; sequelae; trimester; mouse model

\section{Introduction}

The World Health Organization declared the outbreak of Zika virus (ZIKV) infection in the American continent as a public health emergency of international concern in 2016. ZIKV causes a spectrum of congenital abnormalities including fetal loss, intrauterine growth restriction (IUGR), neonatal death, and microcephaly, together termed congenital Zika syndrome (CZS), which is likely associated with complex and life-long disabilities in children born to women infected with ZIKV during pregnancy [1-6]. Postnatal developmental sequelae, such as gross motor impairment, delayed neurodevelopment, cognitive impairment, auditory abnormalities, and/or ophthalmological abnormalities have also been recognized after congenital ZIKV infection, [7-16]. Some children who were asymptomatic with normal head circumferences at birth also developed postnatal symptoms $[7,8,14,17,18]$. 
CZS or developmental sequelae was recognized regardless of the trimesters in which the pregnant mothers were infected [1,7,18-20], although ZIKV infection in the first trimester has been thought to be a risk factor for severe CZS [21-25]. In line with this, a series of murine pregnancy models have been established [26-37]; however, each model recapitulated only some of the fetal or postnatal symptoms seen in human cases (Supplemental Table S1). Moreover, the embryonic ages of congenital ZIKV infection and inspection of offspring, virus strain, infection dose, or route of infection were not consistent in the mouse models (Supplemental Table S1), and how these differences affect the outcomes remains elusive. In this study, IFN $\alpha / \beta$ receptor knockout $\left(\mathrm{IFNAR}^{-/-}\right.$) dams that were crossed with wild-type sires were infected subcutaneously (s.c.) with ZIKV at various embryonic days, and a series of fetal and postnatal outcomes were comprehensively evaluated.

\section{Materials and Methods}

\subsection{Ethics Statement}

All mouse experiments were conducted in accordance with the Guidelines for Animal Experiments performed at the National Institute of Infectious Diseases (NIID) or the Australian Code for Care and Use of Animals for Scientific Purposes, as outlined by the National Health and Medical Research Council of Australia. Animal experiments were approved by the Animal Welfare and Animal Care Committee of NIID (Ethics numbers: 116123 and 119155) or the QIMR Berghofer Medical Research Institute Animal Ethics Committee (Ethics number: A1604-611M). All mice were bred and housed under specific pathogen-free conditions.

\subsection{Cell and Virus Stocks}

Vero (strain 9013, JCRB9013, the Japanese Collection of Research Bioresources Cell Bank, Osaka, Japan) and C6/36 cells (CRL1660, the American Type Culture Collection Manassas, VA, USA) were maintained in Eagle's minimum essential medium (MEM) supplemented with $10 \%$ fetal bovine serum (FBS) and $100 \mu \mathrm{g} / \mathrm{mL}$ penicillin-streptomycin (Life Technologies, Carlsbad, CA, USA). Vero cells and C6/36 cells were cultured at $37{ }^{\circ} \mathrm{C}$ and $28{ }^{\circ} \mathrm{C}$, respectively, in a $5 \% \mathrm{CO}_{2}$ atmosphere. ZIKV strain PRVABC59 (GenBank accession no. KU501215), which was isolated from a patient in Puerto Rico in 2015 [38], was kindly provided by Dr. Beth Bell of the US Center for Disease Control and Prevention. E protein amino acid position 330 of PRVABC59 was a mixture of V and L, as previously reported [39,40]. Natal RGN strain (GenBank accession no. KU527068) was isolated from human fetal autopsy cases with microcephaly in Brazil and prepared as previously described [26,41,42]. ZIKV stocks were tittered by plaque assay on Vero cells, as described previously $[43,44]$.

\subsection{Virus Titration}

Indicated tissues and serum obtained from the blood of the tail vein were collected at the specified time points and stored at $-80^{\circ} \mathrm{C}$ until analysis. The tissues were homogenized in MEM containing $2 \%$ FBS (2MEM) using a tissue homogenizer and beads (Bio Medical Science, Tokyo, Japan) according to the manufacturer's instructions. The $50 \%$ cell culture infective dose $\left(\mathrm{CCID}_{50}\right)$ assays for serum and supernatants from homogenized tissues were performed as described previously [26,40-43,45,46].

\subsection{Reverse Transcription Quantitative PCR ( $q R T-P C R)$}

qRT-PCR was performed as described previously $[40,42,45,46]$. Briefly, tissues were placed in RNAlater (Ambion, Austin, TX, USA), and RNA was extracted with TRIzol (Life Technologies, Carlsbad, CA, USA) from homogenized tissues prepared by bead homogenization. cDNA was generated using an iScript cDNA Synthesis Kit (Bio-Rad, Hercules, CA, USA). qPCR was performed using iTaq Universal SYBR Green Supermix (Bio$\mathrm{Rad}$ ) and the following primers: ZIKV E-Forward, 5'-CCGCTGCCCAACACAAG-3'; ZIKV E-Reverse, 5'-CCACTAACGTTCTTTTGCAGACAT-3'; ZIKV prM-Forward, TTGGTCAT 
GATACTGCTGATTGC-3'; and ZIKV prM-Reverse, $5^{\prime}$-CCTTCCACAAAGTCCCTATTGC$3^{\prime}$ [47]. Values were normalized using the housekeeping gene mouse RPL13A (Forward, $5^{\prime}-$ GAGGTCGGGTGGAAGTACCA-3'; Reverse, 5' -TGCATCTTGGCCTTTTCCTT-3') [48,49].

\subsection{Histology and Immunohistochemistry (IHC)}

Tissue samples were fixed in 10\% phosphate-buffered formalin, embedded in paraffin, sectioned, and stained with hematoxylin and eosin (H\&E). IHC was performed using an anti-ZIKV NS1 antibody (C01886G, Meridian Bioscience, Cincinnati, OH, USA) as the primary antibody $[40,43]$. Specific antigen-antibody reactions were visualized by 3,3diaminobenzidine tetrahydrochloride staining using a VECTASTAIN ABC HRP system (Vector Laboratories, Burlingame, CA, USA).

\subsection{Mice}

IFNAR $^{-/-}$mice on a C57BL/6J background were bred in-house at NIID [40,43]. Female IFNAR $^{-/-}$mice ( $>7$ weeks old) were paired with C57BL $/ 6 \mathrm{~J}$ mice ( $>8$ weeks old) purchased from SLC Ltd. (Shizuoka, Japan), as described previously [29]. When a plug was detected, this was deemed embryonic day 0.5 (E0.5). Pregnancy was confirmed by weight gain. At the indicated time points, dams were infected s.c. with $1 \times 10^{4}$ plaque-forming unit (PFU) of PRVABC59, euthanized at the indicated time points, and their fetuses and indicated tissues were harvested. The fetal crown rump body length (CRL), head length from the tip of the nose to the occiput, head width, and body weight were measured. For postnatal analyses, the dams were infected s.c. with $1 \times 10^{4}$ PFU of PRVABC59 and monitored until offspring were born. The offspring were monitored every day for 14 days after birth (P14), and their body weights and head diameters were measured from P3 to P11.

For the SmithKline Beecham, Harwell, Imperial College, Royal London Hospital, phenotype assessment (SHIRPA) primary screen [50,51], dams were infected s.c. with $1 \times 10^{4}$ PFU of PRVABC59 at E12.5, and their offspring were monitored until SHIRPA screening was performed at the indicated time points. Offspring born to PRVABC59infected or uninfected dams were weighed at P7 or P8 to confirm their growth; they were otherwise left alone to avoid excessive handling, which may modulate the fear, anxiety, or stress response after development [52,53]. The SHIRPA primary screen was performed as previously described [51] with modifications. Briefly, each mouse was placed in a transparent cylindrical viewing jar $(15 \mathrm{~cm}$ diameter, $11 \mathrm{~cm}$ height) for $5 \mathrm{~min}$ to observe rearing, grooming, respiration rate, and tremor. Subsequently, the mouse was transferred to an arena $(33 \mathrm{~cm}$ wide $\times 55 \mathrm{~cm}$ long $\times 18 \mathrm{~cm}$ height) that consisted of 15 evenly spaced squares $(11 \mathrm{~cm} \times 11 \mathrm{~cm})$ to evaluate transfer arousal and motor behavior; thereafter, palpebral closure, piloerection, gait, pelvic elevation, and tail elevation were observed in the arena. A sequence of manipulations was performed to evaluate touch escape, positional passivity, trunk curl, limb grasping and visual placing, grip strength, body tone, pinna reflex, corneal reflex, tow pinch, and wire maneuver. To complete the assessment, the mice were restrained in a supine position to record autonomic behaviors prior to measurement of the righting reflex, contact righting reflex, and negative geotaxis. Throughout the procedure, vocalization, fear, irritability, and aggression were recorded. All behaviors were scored as previously described [51]. The individual parameters assessed by SHIRPA were grouped into five functional categories: neuropsychiatric state, motor behavior, autonomic function, muscle tone and strength, and reflex and sensory function [54,55]. The neuropsychiatric state includes spontaneous activity, transfer arousal, touch escape, positional passivity, biting, fear, irritability, aggression, and vocalization. Motor behavior includes body position, tremor, locomotor activity, pelvic elevation, tail elevation, gait, trunk curl, limb grasping, wire maneuver, and negative geotaxis. Autonomic function includes respiration rate, palpebral closure, piloerection, skin color, heart rate, lacrimation, salivation, and body temperature. Muscle tone and strength include grip strength, body 
tone, limb tone, and abdominal tone. Reflex and sensory functions include visual placement, pinna reflex, corneal reflex, toe pinch, and righting reflex.

To induce neutralizing antibodies against ZIKV, seven female mice (Group A) and three female mice (Group B) were infected s.c. with $1 \times 10^{4}$ PFU of PRVABC59 40 days before mating. Four female mice (Group C) or one female mouse (Group D) were infected s.c. with $1 \times 10^{4} \mathrm{PFU}$ of PRVABC59 twice at a 57-60 days interval before mating. Ten female mice in Group E were inoculated s.c. with 2MEM twice at a 57-60 day interval before mating. After plugging, the mice were bled and the neutralizing antibody titer was determined by the standard $50 \%$ plaque reduction neutralization $\left(\mathrm{PRNT}_{50}\right)$ assay $[56,57]$. Dams in Groups A, C, and E were infected s.c. with $1 \times 10^{4}$ PFU of PRVABC59 at E9.5, and dams in Groups B and D were inoculated s.c. with 2MEM at E9.5. The offspring were monitored from P1 to P21. For the uninfected control, seven female mice were left without any treatment before mating and during pregnancy.

\subsection{Statistical Analyses}

The Student's $t$-test was performed for normally distributed data sets where differences in variance were $<4$, skewness was $>-2$, and kurtosis was $<2$. The KolmogorovSmirnov test was used for non-parametric data where differences in variance were $>4$, skewness was $<-2$, and kurtosis was $>2$. The log-rank test was used for the statistical analysis of survival rates. Repeated-measures ANOVA was used to determine differences in postnatal growth over time. Pearson or Spearman correlation analyses were performed for normally distributed data or non-parametric data, respectively. Statistical significance was set at $p<0.05$. Statistical analysis of the experimental data was performed using JMP 13 software (SAS Institute, Inc., Cary, NC, USA).

\section{Results and Discussion}

\subsection{Fetal Outcomes}

To assess fetal outcomes after congenital ZIKV infection, dams were s.c. infected with PRVABC59 at E6.5, E7.5, E8.5, E9.5, E10.5, E11.5, E12.5, E13.5, and E14.5, and the fetuses were visually inspected at 6 days post-infection (dpi; Figure 1A). Most of the fetuses infected at E6.5, E7.5, and E8.5 (100\%, 100\%, and 75\%, respectively) showed abnormalities (IUGR, deformed fetal/placental masses, or fetal death). The number of infected embryonic days was inversely correlated with the prevalence of IUGR or deformed masses (Figure 1B,C). The CRL (Figure 1D insert), head length from the tip of the nose to the occiput (Figure 1E insert), and weight of infected fetuses were significantly smaller than those of uninfected fetuses (Figure 1D-F). The fetal CRL and head length from the tip of the nose to the occiput were measured to provide evidence for IUGR and to predict fetal cranium growth, respectively [37,58]. The lower prevalence of fetuses with gross abnormalities after infection at or after E9.5 (Figure 1A-C) was confirmed by visual inspection at 2 and 4 dpi at E9.5 and E13.5 (Figure 1G). In addition, intracranial hemorrhage (Figure $1 \mathrm{H}$ ) and ocular malformation (Figure 1I), which were similar to those observed in human neonates with CZS [59-62], were observed in fetuses after infection at E13.5. Thus, ZIKV infection during early pregnancy between E6.5-E8.5, corresponding to the first trimester in humans [63], was a significant risk factor for severe fetal outcomes, such as fetal death, resorption (observed as deformed fetal/placental masses), and severe IUGR, whereas infection at or after E9.5 caused relatively mild outcomes (Figure 1D-F), but did not enhance fetal lethality (Figure 1A). Thus, the embryonic timing of congenital ZIKV infection affects the severity of fetal outcomes. 
(A)

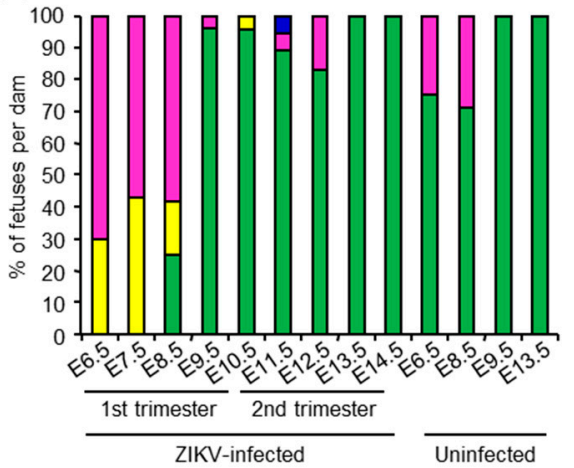

(B)

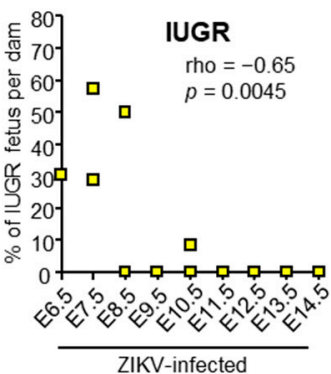

(C)

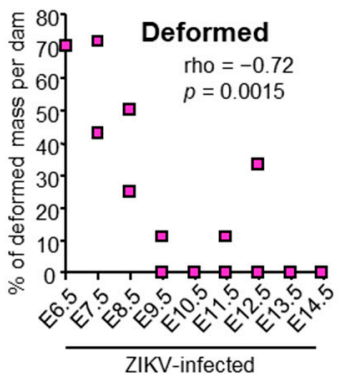

Dead - no heart beating or no pulsation of the umbilical cord

$\square$ Deformed fetal/placental mass $\square$ IUGR - visually evaluated

$\square$ Normal

(D) CRL aZIKV ם Uninfected

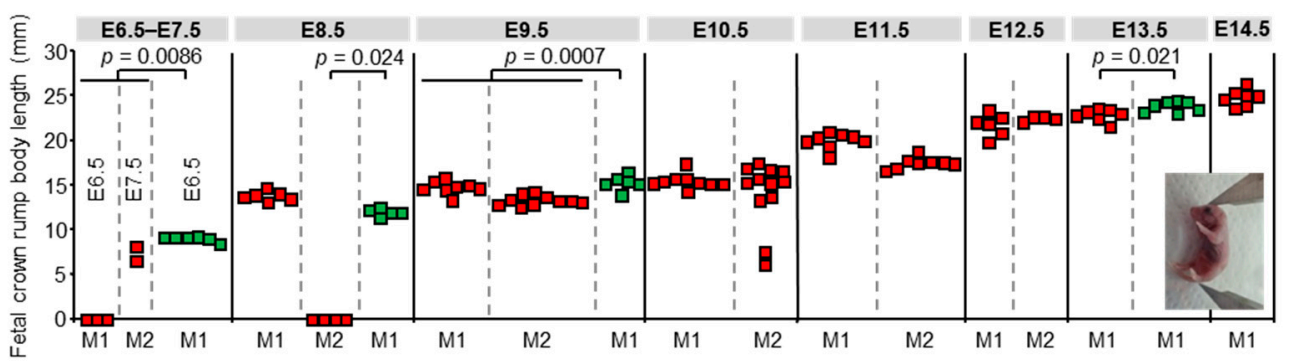

(E) Head length aZIKV ם Uninfected

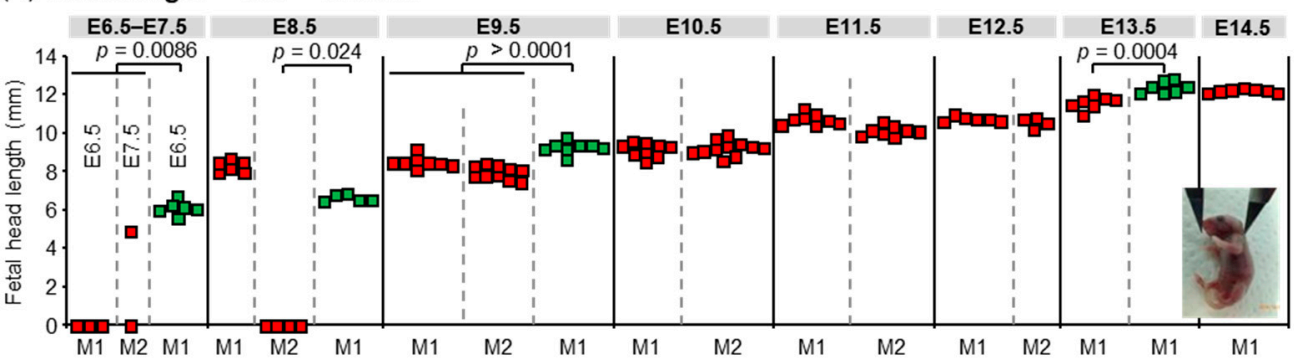

(F) Weight $\square$ ZIKV ם Uninfected

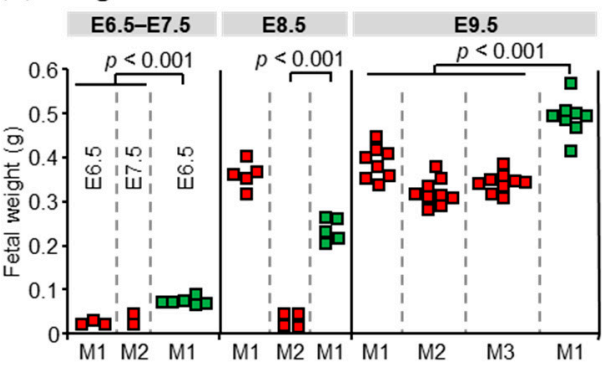

(G)
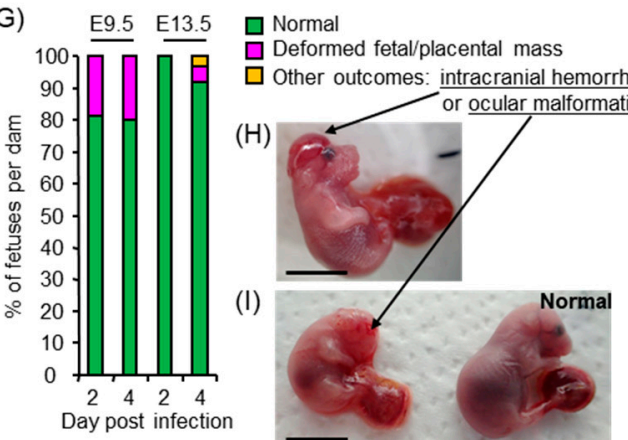

Figure 1. Fetal outcomes. (A) Percentages of each fetal outcome: fetuses that died in utero, were deformed, showed IUGR, or appeared normal at 6 days after congenital ZIKV infection. Survival of fetuses was confirmed by heartbeat or pulsation of the umbilical cord as observed under a microscope. The $x$-axis shows the embryonic days of ZIKV infection or 2MEM inoculation for uninfected controls. The ZIKV-infected group consisted of 10 fetuses from 1 dam infected at E6.5, 14 fetuses from 2 dams infected at E7.5, 22 fetuses from 3 dams infected at E8.5, 28 fetuses from 3 dams infected at E9.5, 21 fetuses from 2 dams infected at E10.5, 17 fetuses from 2 dams infected at E11.5, 13 fetuses from 2 dams infected at E12.5, and 7 fetuses from 1 dam infected at E13.5 or E14.5. The uninfected group consisted of 8 fetuses from 1 dam at E6.5 or E9.5 and 7 fetuses from 1 dam at E8.5 or E13.5. (B) Inverse correlation between IUGR prevalence at 6 dpi and infected embryonic days. The $x$-axis shows ZIKV-infected embryonic days. Significance was determined by Spearman's correlation 
test. (C) Inverse correlation between the prevalence of deformed masses at 6 dpi and infected embryonic days. The $x$-axis shows ZIKV-infected embryonic days. Significance was determined by Spearman's correlation test. (D) Fetal CRL at 6 dpi. Dams were infected with ZIKV or inoculated with 2MEM (uninfected) at the indicated embryonic days. Individual dams are indicated on the $x$-axis; each square represents one fetus. Vertical dashed gray lines separate litters from each dam. If the fetal heads were indistinguishable from the body, their CRL was considered as zero (below the detection limit). Significance was determined by $t$-test or Kolmogorov-Smirnov test. (E) Fetal head length at 6 dpi. Data are from the same fetuses as described for panel C. If the fetal heads were indistinguishable from the body, their head length was considered as zero (below the detection limit). Significance was determined by $t$-test or Kolmogorov-Smirnov test. (F) Fetal weights at 6 dpi. Dams were infected with ZIKV or inoculated with 2MEM (uninfected) at the indicated embryonic days. Individual dams are indicated on the $x$-axis; each square represents one fetus. Vertical dashed gray lines separate litters from each dam. Significance was determined by $t$-test. (G) Percentages of each fetal outcome at 2 or 4 dpi. Dams were infected with ZIKV at E9.5 or E13.5, and fetuses were visually inspected at 2 or 4 dpi. The data include 18 fetuses from 2 litters at 2 dpi at E9.5, 10 fetuses from 1 litter at $4 \mathrm{dpi}$ at E9.5, 4 fetuses from 1 litter at $2 \mathrm{dpi}$ at E13.5, or 75 fetuses from 8 litters at $4 \mathrm{dpi}$ at E13.5. (H) The fetus with intracranial hemorrhage at $4 \mathrm{dpi}$ at E13.5. Scale bar $=1 \mathrm{~cm}$. (I) The fetus with ocular malformation and an apparently normal littermate. Scale bar $=1 \mathrm{~cm}$.

\subsection{Fetal and Placental Infection}

To confirm the vertical transmission of ZIKV, viral titers in the placentas, fetal whole bodies, and deformed masses at $6 \mathrm{dpi}$ were determined by $\mathrm{CCID}_{50}$ assays. Most placentas were infected irrespective of the infected embryonic days, whereas the titer of most fetuses was lower than the detection limit at 6 dpi (Figure 2A). To assess whether ZIKV did not transmit to fetuses or did not replicate in fetal tissues, or whether active virus replication decreased to undetectable levels before $6 \mathrm{dpi}$, the placentas and fetal tissues were collected at 2 or 4 dpi at E9.5-E10.5 (first trimester in humans) or E12.5 (second trimester in humans) and tissue virus titers determined. The fetal heads were titrated rather than the whole body, except for fetal samples collected at $2 \mathrm{dpi}$ at E9.5, as the fetal heads were indistinguishable from the body. A total of $60 \%$ and $100 \%$ of fetuses in each dam infected at E9.5 and $60 \%$, $20 \%$, and $16.7 \%$ of fetuses in each dam infected at E12.5 were infected at $2 \mathrm{dpi}$; all fetuses were infected by 4 dpi with a similar titer after infection at E9.5-E10.5 and E12.5 ( $p=0.97$, Figure 2B). The virus titers were similar in each tissue of dams infected at E9.5-E10.5 and E12.5 (Supplemental Figure S1), showing that the dams were equally susceptible to ZIKV infection irrespective of embryonic days, as previously reported [64]. The placental virus titers were not different after infection at E9.5-E10.5 and E12.5 (Figure 2B, $p=0.053$ for $2 \mathrm{dpi}, p=0.13$ for $4 \mathrm{dpi}$ ), with no correlation in virus titers between the fetal heads and corresponding placentas (Figure 2C, $p=0.47$ for $2 \mathrm{dpi}, p=0.17$ for $4 \mathrm{dpi}$ ). The placentas at 6 dpi at E8.5, E9.5, or E13.5 were smaller than uninfected placentas (Figure 2D) as previously reported [29]. However, histological abnormality was not observed in placentas from infected dams (Figure 2E,F,I,J). In addition, viral antigens were found only in the histologically normal decidual cells in the peripheral area of placentas by IHC with antiNS1 antibody (Figure 2G,H,K,L). The mouse placenta forms a definitive structure and becomes functional around E10.5-E11.5 [65,66]. The infection of fetal heads after E12.5 infection suggests that ZIKV crossed the placental barrier. Taken together, fetuses were infected congenitally, irrespective of gross abnormalities (Figure 1) or embryonic days of congenital infection. The former observation is partially consistent with previous work in which ZIKV RNA was detected in the fetal heads with only mild IUGR after infection at E6.5 or E7.5 [29]. 
(A) 6 dpi $\square$ Fetal whole body $\square$ Placenta $\square$ Deformed

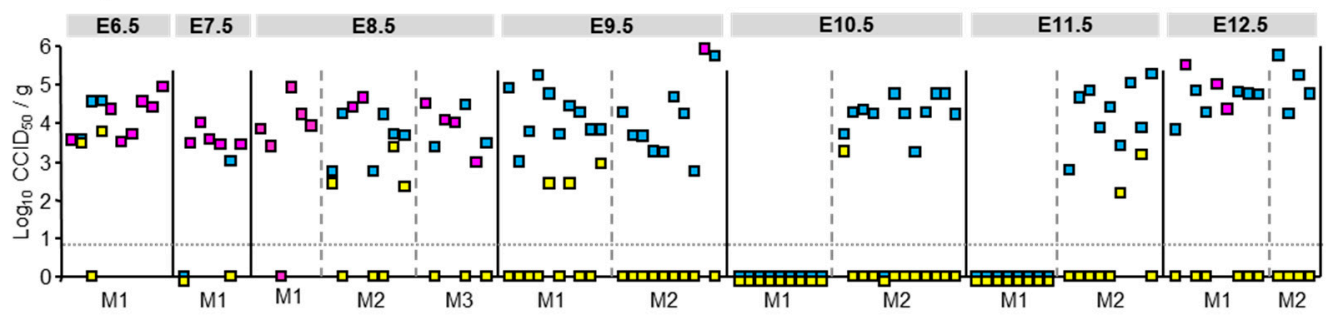

(B) $\square$ Fetal head $\square$ Placenta $\square$ Deformed

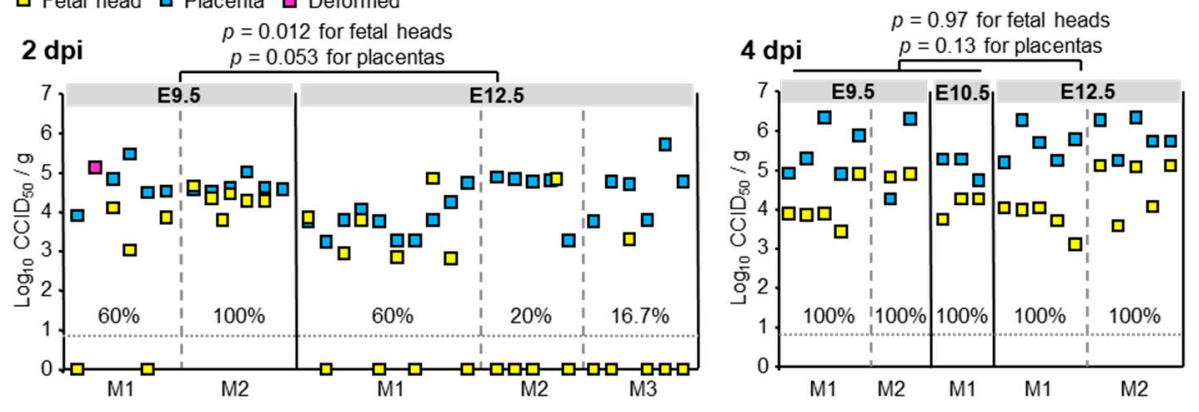

(C) $\square \mathrm{E} 9.5-\mathrm{E} 10.5 \mathrm{aE} 12.5$
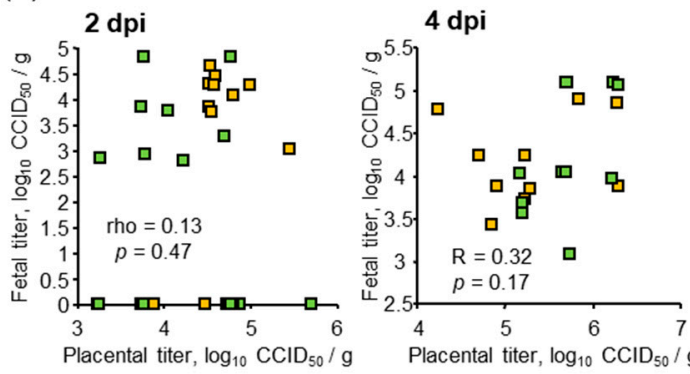

(D) Placental weight $\square$ ZIKV םUninfected
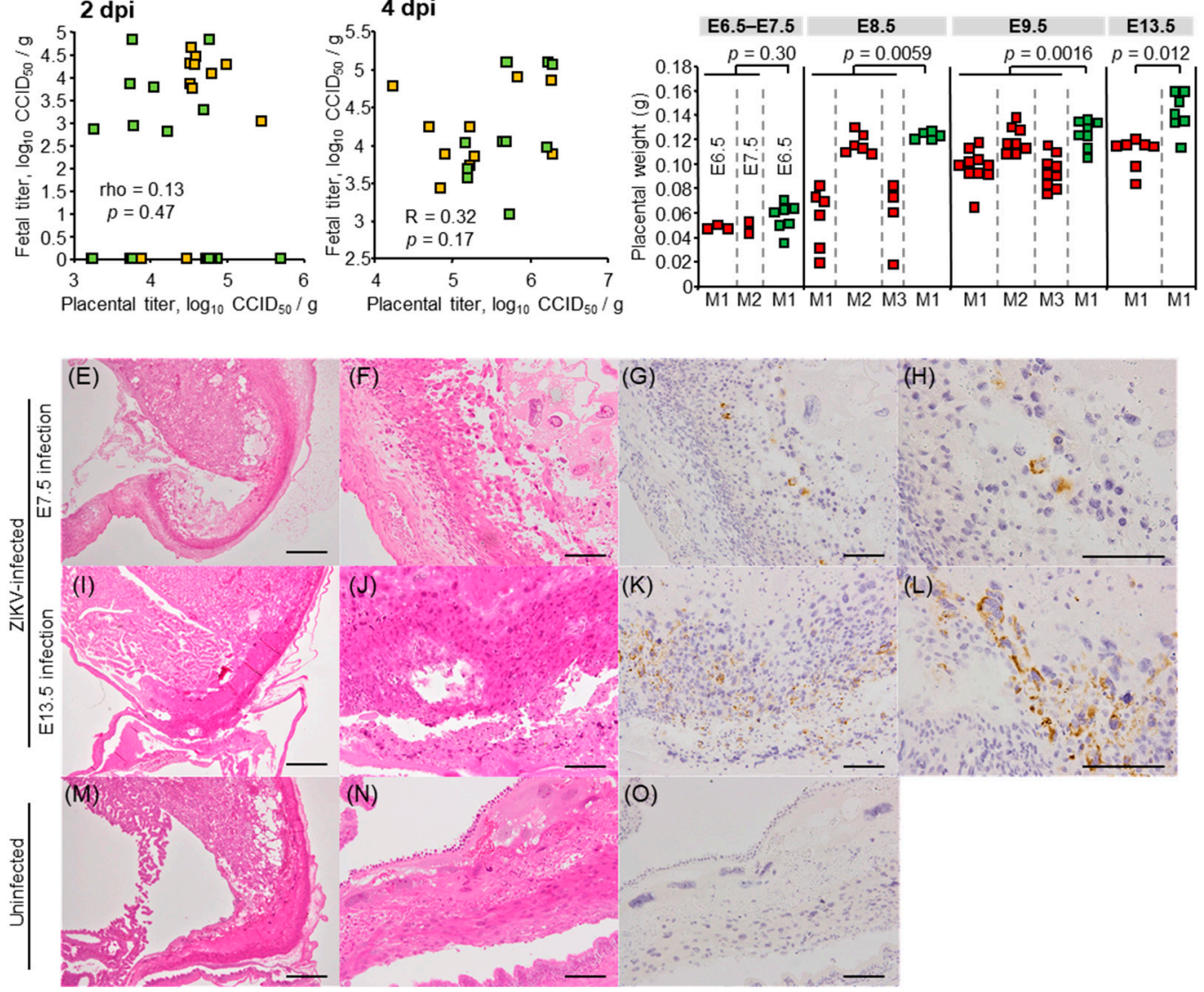

Figure 2. Viral titers and histological findings in fetal tissues or placentas. (A) Viral titers in fetal whole bodies, placentas, and deformed masses at $6 \mathrm{dpi}$. Dams were infected with ZIKV at the indicated embryonic days. Individual dams are indicated on the $x$-axis. Vertical dashed gray lines separate litters from each dam. Symbols represent individual fetus, placenta, or deformed mass. Limit of detection was $0.83 \log _{10} \mathrm{CCID} 50 / \mathrm{g}$ as indicated by the horizontal dashed line. (B) Viral titers in fetal heads, placentas, and deformed masses at 2 or $4 \mathrm{dpi}$, as described for panel A. Percentage of fetuses that were infected for each dam at 2 or $4 \mathrm{dpi}$ is indicated. Kolmogorov-Smirnov test or $t$-test was used for statistical analysis. (C) Lack of correlation between virus titers in placentas and fetal heads at $2 \mathrm{dpi}$ and $4 \mathrm{dpi}$ as determined by Pearson or Spearman's correlation test. (D) Placental weights at 6 dpi. Dams were infected with ZIKV or inoculated with 2MEM (uninfected) at the 
indicated embryonic days. Individual dams are indicated on the $x$-axis; each square represents one placenta. Significance was determined by $t$-test or Kolmogorov-Smirnov test. (E) H\&E staining of placentas at 6 dpi; dams were infected at E7.5. Representative image of placentas from 2 dams. (F) As described for panel E at higher magnification. (G) IHC of placenta at $6 \mathrm{dpi}$ at E7.5 using anti-ZIKV NS1 antibody. Positive staining (brown) was detected in decidual cells. Representative image of placentas from 2 dams. (H) As described for panel $G$ at higher magnification. (I-L) H\&E staining and IHC of placentas at 6 dpi; dams were infected at E13.5; otherwise as described for E-H. (M) H\&E staining of placentas from uninfected dams. Representative image of placentas from 2 dams. (N) As described for panel M at higher magnification. (O) IHC of placenta from uninfected dams using anti-ZIKV NS1 antibody. Representative image of placentas from 2 dams. Scale bars; $500 \mu \mathrm{m}$ (E,I,M), $100 \mu \mathrm{m}(\mathbf{F}-\mathbf{H}, \mathbf{J}-\mathbf{L}, \mathbf{N}, \mathbf{O})$.

\subsection{Postnatal Outcomes}

To assess postnatal outcomes, dams were infected with PRVABC59 at E8.5, E9.5, E10.5, E11.5, E12.5, E13.5, and E14.5, and their offspring were monitored from P1 to P14, including measuring body weight and head circumference from P3 to P11. All offspring born to dams infected at E8.5 or E9.5, died within one day after birth (Figure 3A). The survival of offspring born to dams infected at E10.5-E14.5 was significantly lower than that of uninfected offspring ( $p=0.0007$ for E10.5, $p<0.0001$ for E11.5, $p=0.0005$ for E12.5, $p=0.042$ for E13.5, and $p<0.0001$ for E14.5) (Figure 3A). Human infants with congenital ZIKV infection are typically small for gestational age (SGA) [1] and/or exhibit failure to thrive (FTT) [16]. SGA is defined as a birth weight at least two standard deviations (SDs) below the mean for gestational age [67]. FTT is defined as subnormal growth or subnormal weight gain in infants [68]. The weight of two litters (L1 and L2) infected at E12.5, and one offspring infected at E13.5, was less than 2SD of the mean weight of uninfected offspring at P3, which was the earliest time point of weight measurement (Figure 3B). The weights of offspring infected at E10.5 or E11.5 were comparable with those of uninfected offspring (Figure 3B). There was variability in offspring weights between litters (e.g., L1/L2 versus L3 after infection at E12.5). The absence of significance in offspring weights after infection at E10.5 or E11.5 when compared with uninfected offspring thus may be explained by the small sample size, which is a limitation of our study. The mean weight gain of L1 and L2 infected at E12.5 (Figure 3C) was lower than that of uninfected offspring $(p<0.0001$ for L1, $p=0.0005$ for L2), suggesting SGA and FTT. Microcephaly is defined postnatally as a small head circumference $\geq 2$ SDs of the norm $[69,70]$. The head circumferences of L1 and one offspring from L2 infected at E12.5, were smaller than 2SD of the mean of uninfected offspring at P3 (Figure 3D). The mean head circumferences at P3-P11 of L1 infected at E12.5, at P3, P7, P8, P9, and P10 of L2 infected at E12.5, and at P5 and P6 of L1 infected at E13.5 were smaller than 2SD of the uninfected mean (Figure 3E), suggesting microcephaly. Thus, our mouse model recapitulates multiple postnatal outcomes including stillbirths (Figure 3A), neonatal death (Figure 3A), SGA (Figure 3B), FTT (Figure 3B,C), and microcephaly (Figure 3D,E), as observed in human cases $[1,13,15,17,71]$.

To evaluate the outcomes in grown-up mice after congenital ZIKV infection, SHIRPA primary screening was performed on 4-week-old mice born to dams infected with PRBVABC59 at E12.5. Two mice born to dams infected at E12.5, were smaller than each littermate and died at P10 before SHIRPA was performed (Figure 3F). The SHIRPA scores of infected mice were compared with two age-matched control groups: (1) 2MEM inoculation at E12.5, or (2) no treatment during pregnancy and postnatal periods. The reduced body weight of infected mice (Figure 3G) was consistent with previous data (Figure 3B,C). Two mice remained small during adulthood (10-week-old) and reached the ethical endpoint for euthanasia at 10 weeks after birth (Supplemental Figure S2A), although the survival between the three groups did not reach statistical significance (Supplemental Figure S2B). Infected offspring had significantly deficient SHIRPA scores compared with 2MEM-inoculated and/or untreated offspring in 11 tests belonging to four SHIRPA functional categories (Figure 3G): neuropsychiatric state (touch escape, positional passivity, provoked biting, irritability, and aggression), motor behavior (limb grasping and negative geotaxis), autonomic function (salivation and body temperature), and reflex and sensory functions (visual 
placing and toe pinch). The abnormalities in the SHIRPA screen were also confirmed in IFNAR $^{-/-}$offspring born to dams infected with the Natal RGN strain at E6.5. The mean body weight of one of the five litters infected with Natal RGN at E6.5 was lower than that of the uninfected litter at 3 weeks post-birth (Supplemental Figure S3A). The infected litter had abnormal scores in four tests: locomotor activity, tail elevation, gait, and grip strength (yellow boxes in Supplemental Figure S3A). Another infected litter showed an abnormality in a fifth test, namely, provoked biting (green box in Supplemental Figure S3A). The five tests belonged to three functional categories: neuropsychiatric state (provoked biting), motor behavior (locomotor activity, tail elevation, and gait), and muscle tone and strength (grip strength). ZIKV RNA was detected in the testis of one male offspring born to a Natal RGN-infected dam (Supplemental Figure S3B), confirming vertical transmission and offspring infection. Thus, our mouse model recapitulates a wide range of postnatal developmental sequelae $[7,8,14,17,18]$.

(A)

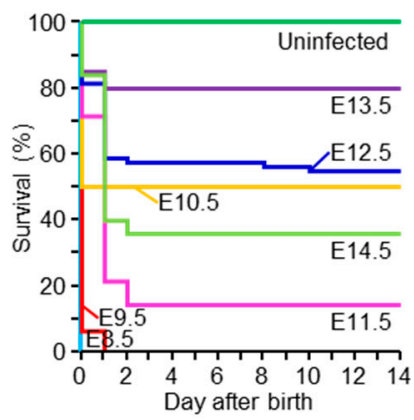

Uninfected vs E8 $5, p<0.0001$

$\mathrm{E} 9.5, p<0.0001$

$\mathrm{E} 10.5, p=0.0007$

$\mathrm{E} 11.5, p<0.0001$

$\mathrm{E} 12.5, p=0.0005$

$\mathrm{E} 13.5, p=0.042$

$\mathrm{E} 14.5, p<0.0001$

(D) Head circumference at P3

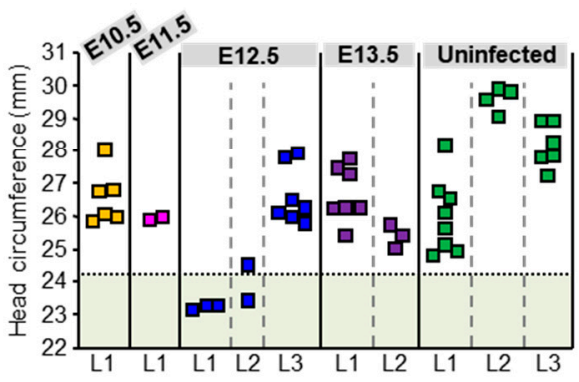

(B)

\section{Weight at $\mathbf{P} 3$}

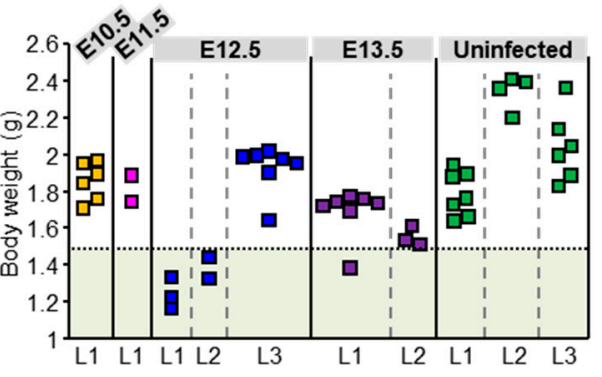

(C)

\section{Weight gain}

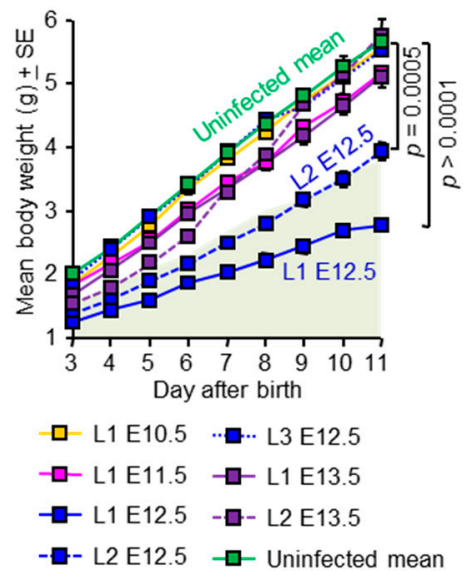

(F) Weight at P7 or P8

(E) Growth of head circumference

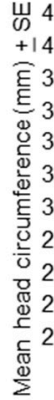
$\stackrel{\mathbb{\infty}}{\Sigma}$

$$
\square
$$$$
\rightarrow-\text { L1 E12.5 - - - L2 E13.5 }
$$

Figure 3. Cont. 
(G)

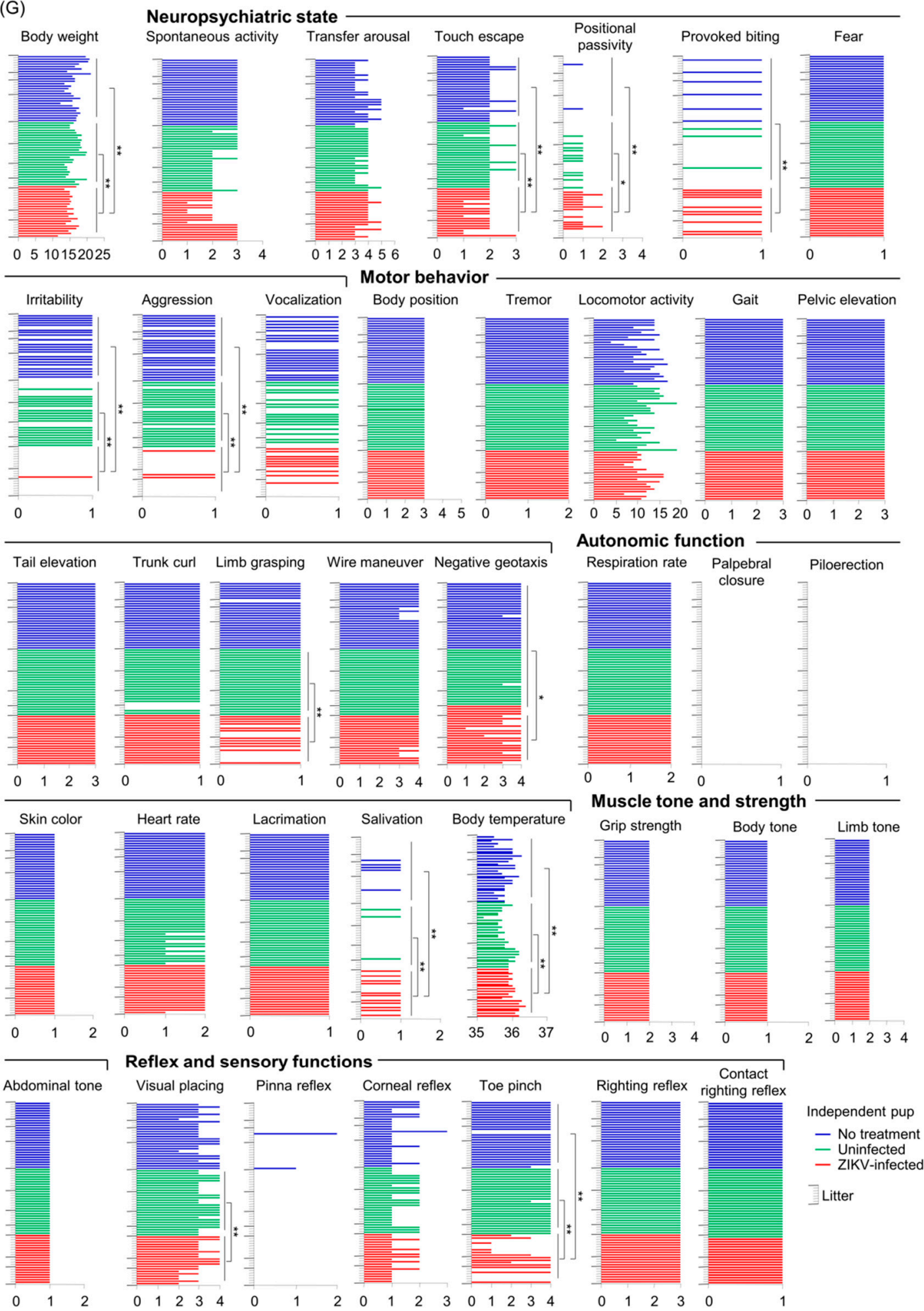

Figure 3. Postnatal outcomes. (A) Survival of offspring. Data are from 8 offspring from 1 dam infected at E8.5, 16 offspring from 3 dams infected at E9.5, 12 offspring from 2 dams infected at E10.5, 14 offspring from 2 dams infected at E11.5, 75 offspring from 9 dams infected at E12.5, 20 offspring from 3 dams infected at E13.5, 25 offspring from 4 dams infected at E14.5, and 19 offspring from 3 uninfected dams. Comparison of Kaplan-Meier survival curves between groups was performed by log-rank analysis. (B) Weight of offspring at P3. Individual litters are indicated on the $x$-axis; each square represents a single offspring. Vertical dashed gray lines separate each litter, which was infected at the indicated embryonic days. The pale green shaded area represents 2 SD below the mean body weight of uninfected offspring. (C) Weight gain of 
each litter. The pale green shaded area represents 2SD below the mean body weight of uninfected offspring. Data consist of 6 survived offspring out of 8 offspring (6/8) for litter 1 (L1) infected at E10.5, 2/ 7 for L1 infected at E11.5, 3/5 for L1 infected at E12.5, 2/4 for L2 infected at E12.5, $7 / 7$ for L3 infected at E12.5, $7 / 7$ for L1 infected at E13.5, and 3/5 for L2 infected at E13.5. The uninfected group consisted of 18 offspring from 3 litters. Statistical analyses were performed by repeated-measure ANOVA. (D) Head circumference of offspring at P3. Individual litters are indicated on the $x$-axis; each square represents a single offspring. Vertical dashed gray lines separate each litter, which was infected at the indicated embryonic days. The pale green shaded area represents 2SD below the mean head circumference of uninfected offspring. Head circumference was calculated by multiplying the head diameter by Pi (3.14). (E) Growth of head circumference of each litter. Data are from the same litters as described for panel C. The pale green shaded area represents 2SD below the mean head circumference of uninfected offspring. Asterisks show the value 2SD below that of the uninfected mean. (F) Weight of offspring born to ZIKV-infected or uninfected dams at P7 or P8. Individual litters are indicated on the $x$-axis; each square represents a single offspring. Vertical dashed gray lines separate each litter, which was infected at E12.5 or uninfected. Dorsal view of two small offspring infected at E12.5 compared with each littermate. (G) SHIRPA scores of 4-week-old mice born to ZIKV-infected dams at E12.5. The horizontal axis shows the score. Each bar represents one mouse. Statistical analyses were performed by Kolmogorov-Smirnov test or $t$-test: ${ }^{*} p<0.05$; ${ }^{* *} p<0.01$. Longer lines along the $y$-axis separate litters.

\subsection{Maternal Neutralizing Antibodies Prevent Offspring Outcomes}

To demonstrate the utility of our model, we performed a proof of principal experiment testing whether neonatal death could serve as criteria for screening of ZIKV vaccine candidates. There are no vaccines currently available for ZIKV infection, and female mice were infected with ZIKV prior to mating to induce neutralizing antibodies, which alone were sufficient to prevent vertical transmission of ZIKV in mice [72]. The dams were infected with ZIKV at E9.5, which caused neonatal death (Figure 3A), and the survival of their offspring was monitored. The experimental scheme is shown in Figure 4A. Briefly, female mice were infected with PRVABC59 40 days before mating (Groups A and B) or infected twice with a 57-60 days interval before mating (Groups $C$ and D). Females in Group E were inoculated with $2 \mathrm{MEM}$ before mating. An increased neutralizing antibody titer was detected after plugging in Groups A, B, C, and D when compared with Group E or uninfected group (Figure 4B). Pregnant mice in Groups A, C, and E were infected s.c. with PRVABC59 at E9.5, whereas pregnant mice in Groups B and D were inoculated with 2MEM at E9.5. The survival of offspring in Groups $A$ and $C$ was significantly improved compared with Group E ( $p<0.0001$, Figure 4 C). The 1-day-old offspring in Groups A and D were visually larger than those in Group E (Supplemental Figure S4). The survival of each litter infected at E9.5 (Groups A, C, and E) was correlated with the neutralizing antibody titer of each dam $(p=0.0011$, Figure $4 \mathrm{D})$. Taken together, the results demonstrated that maternal neutralizing antibodies (at least a PRNT titer of 1:10 2.8 , Figure 4B,D) prevent neonatal death in mice, and that neonatal death can serve as an in vivo phenotypic readout for screening the efficacy of candidate vaccines against ZIKV. 
(A)
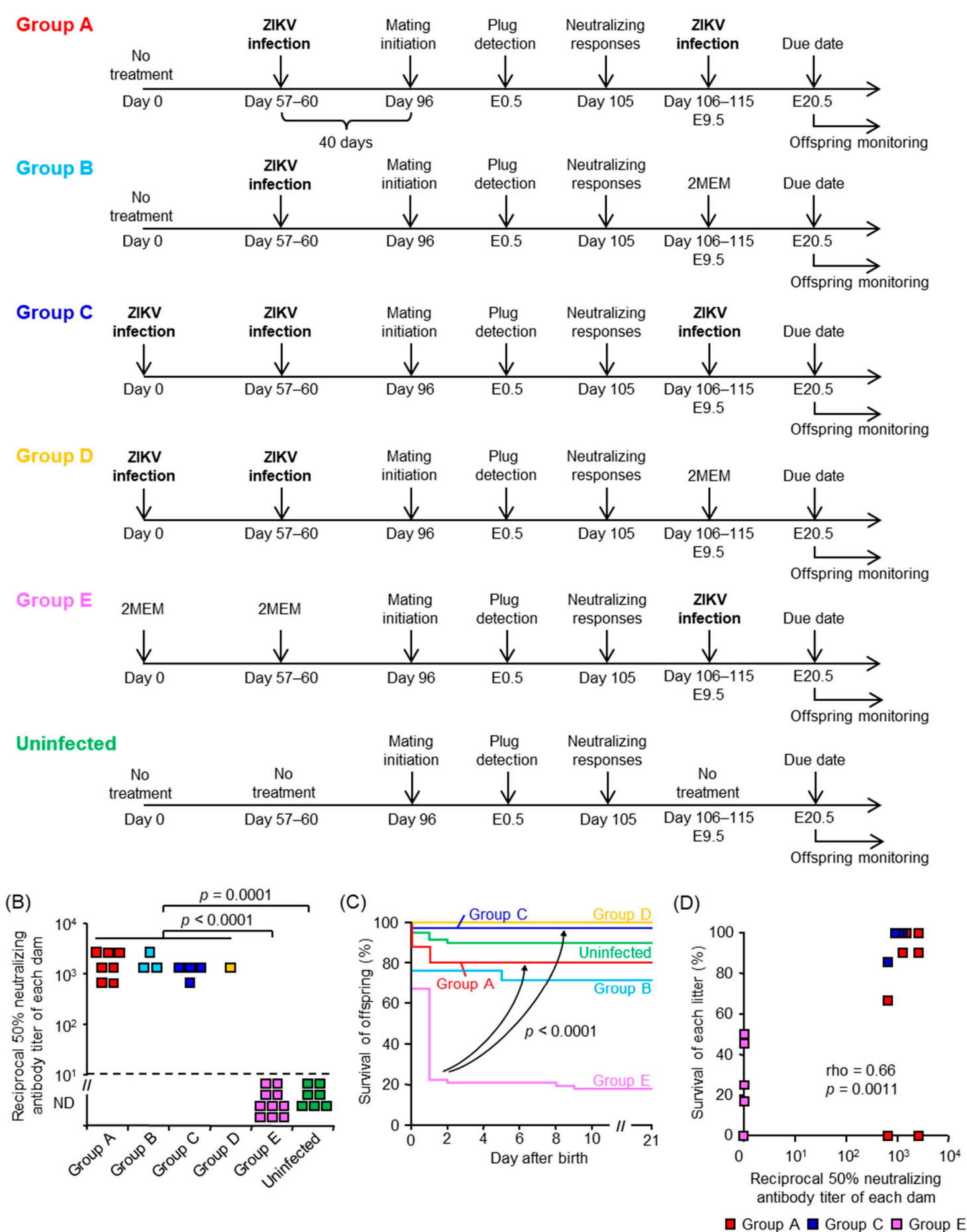

Figure 4. Neutralizing antibodies in dams protect the offspring from vertical ZIKV infection. (A) Experimental timeline of each group. (B) ZIKV-specific neutralizing antibody titers of each dam. Limit of detection was 1 in 10 dilutions as indicated by the horizontal dashed line. Titer was determined by PRNT $_{50}$ assays. Kolmogorov-Smirnov test was used for statistical analysis. (C) Survival of offspring. Comparisons for Group E versus either Group A or Group C, $p<0.0001$. Comparisons of Kaplan-Meier survival curves between the different groups were performed by log-rank analyses. The data are from 51 offspring from 7 litters for Group A, 21 offspring from 3 litters for Group B, 35 offspring from 4 litters for Group C, 6 offspring from 1 litter for Group D, 67 offspring from 10 litters for Group E, and 60 offspring from 7 litters for the uninfected group. (D) Correlation between neutralizing antibody titers of each dam and the percent survival of each litter in Groups A, C, and E. Significance was determined by Spearman's correlation test. 


\section{Conclusions}

Our mouse pregnancy model recapitulated multiple fetal and postnatal outcomes seen in humans after congenital ZIKV infection. The embryonic timing of ZIKV infection affected the outcomes; infection during early pregnancy caused fetal death and severe IUGR, and infection during mid to late pregnancy caused stillbirth, neonatal death, SGA, FTT, microcephaly, or developmental sequelae. Furthermore, neonatal death in our model may be useful as a readout phenotype to evaluate the efficacy of ZIKV vaccine candidates.

Supplementary Materials: The following are available online at https://www.mdpi.com/article/ 10.3390/v13091807/s1, Figure S1: Virus titers in maternal tissues, Figure S2: Offspring infected at E12.5 in adulthood, Figure S3: Offspring outcomes after ZIKV Natal RGN infection, Figure S4: Size of one-day-old offspring, Table S1: Mouse pregnancy models. References [73-77] are cited in supplemental materials.

Author Contributions: Conceptualization, E.N.; methodology, E.N., Y.K., J.E.H., B.T. and A.S.; formal analysis, E.N. and J.E.H.; investigation, E.N., Y.K., S.T. (Satoshi Taniguchi), J.E.H., K.-i.S., K.T., Y.S., B.T., K.Y., N.K., C.K.L. and T.S.; data curation, E.N., S.T. (Satoshi Taniguchi) and J.E.H.; writingoriginal draft preparation, E.N.; writing—review and editing, E.N., S.T. (Satoshi Taniguchi), K.T. and C.K.L.; supervision, A.S. and M.S.; funding acquisition, E.N., S.T. (Shigeru Tajima), C.K.L. and A.S. All authors have read and agreed to the published version of the manuscript.

Funding: This research was supported by the Research Program on Emerging and Re-emerging Infectious Diseases of the Japan Agency for Medical Research and Development (AMED; https: / /www.amed.go.jp/en/program/list/11/02/002.html; accessed on 26 August 2021), Grant numbers JP19fk0108035, JP20fk0108123 and JP21wm0225007, and JSPS KAKENHI (https:/ /www.jsps.go.jp/ english/index.html; accessed on 26 August 2021), Grant number JP20K07530. E.N. was supported in part by the Daiichi Sankyo Foundation of Life Science, Japan (http:/ /www.ds-fdn.or.jp/support/ studying_abroad.html; accessed on 26 August 2021). A.S. holds an investigator grant (APP1173880) from the National Health and Medical Research Council (NHMRC) of Australia (https:/ /www. nhmrc.gov.au/; accessed on 26 August 2021). The project was also funded in part by an NHMRC project grant, grant number APP1144950. The funders had no role in the study design, data collection and analysis, decision to publish, or preparation of the manuscript.

Institutional Review Board Statement: All mouse experiments were conducted in accordance with the Guidelines for Animal Experiments performed at the National Institute of Infectious Diseases (NIID) or the Australian Code for Care and Use of Animals for Scientific Purposes, as outlined by the National Health and Medical Research Council of Australia. Animal experiments were approved by the Animal Welfare and Animal Care Committee of NIID (Ethics numbers: 116123 and 119155) or the QIMR Berghofer Medical Research Institute Animal Ethics Committee (Ethics number: A1604-611M). All mice were bred and housed under specific pathogen-free conditions.

Informed Consent Statement: Not applicable.

Data Availability Statement: The data presented in this study are available on request from the corresponding author.

Acknowledgments: The authors would like to thank Takahiro Maeki (NIID) for his suggestion, and Makiko Ikeda and Nor Azila Muhammad Azami (NIID) for their technical assistance.

Conflicts of Interest: The authors declare no conflict of interest. The funders had no role in the design of the study; in the collection, analyses, or interpretation of data; in the writing of the manuscript, or in the decision to publish the results.

\section{References}

1. Brasil, P.; Pereira, J.P., Jr.; Moreira, M.E.; Ribeiro Nogueira, R.M.; Damasceno, L.; Wakimoto, M.; Rabello, R.S.; Valderramos, S.G.; Halai, U.A.; Salles, T.S.; et al. Zika Virus Infection in Pregnant Women in Rio de Janeiro. N. Engl. J. Med. 2016, 375, 2321-2334. [CrossRef] [PubMed]

2. Franca, G.V.; Schuler-Faccini, L.; Oliveira, W.K.; Henriques, C.M.; Carmo, E.H.; Pedi, V.D.; Nunes, M.L.; Castro, M.C.; Serruya, S.; Silveira, M.F.; et al. Congenital Zika virus syndrome in Brazil: A case series of the first 1501 livebirths with complete investigation. Lancet 2016, 388, 891-897. [CrossRef] 
3. van der Eijk, A.A.; van Genderen, P.J.; Verdijk, R.M.; Reusken, C.B.; Mogling, R.; van Kampen, J.J.; Widagdo, W.; Aron, G.I.; GeurtsvanKessel, C.H.; Pas, S.D.; et al. Miscarriage Associated with Zika Virus Infection. N. Engl. J. Med. 2016, 375, 1002-1004. [CrossRef] [PubMed]

4. Pereira, J.P., Jr.; Nielsen-Saines, K.; Sperling, J.; Maykin, M.M.; Damasceno, L.; Cardozo, R.F.; Valle, H.A.; Dutra, B.R.T.; Gama H.D.; Adachi, K.; et al. Association of Prenatal Ultrasonographic Findings with Adverse Neonatal Outcomes Among Pregnant Women with Zika Virus Infection in Brazil. JAMA Net. Open 2018, 1, e186529. [CrossRef]

5. de Araújo, T.V.B.; de Alencar Ximenes, R.A.; de Barros Miranda-Filho, D.; Souza, W.V.; Montarroyos, U.R.; de Melo, A.P.L.; Valongueiro, S.; Braga, C.; Brandão Filho, S.P.; Cordeiro, M.T. Association between microcephaly, Zika virus infection, and other risk factors in Brazil: Final report of a case-control study. Lancet Infect. Dis. 2018, 18, 328-336. [CrossRef]

6. de Araújo, T.V.B.; Rodrigues, L.C.; de Alencar Ximenes, R.A.; de Barros Miranda-Filho, D.; Montarroyos, U.R.; de Melo, A.P.L.; Valongueiro, S.; Souza, W.V.; Braga, C.; Brandão Filho, S.P. Association between Zika virus infection and microcephaly in Brazil, January to May, 2016: Preliminary report of a case-control study. Lancet Infect. Dis. 2016, 16, 1356-1363. [CrossRef]

7. Pecanha, P.M.; Gomes Junior, S.C.; Pone, S.M.; Pone, M.; Vasconcelos, Z.; Zin, A.; Vilibor, R.H.H.; Costa, R.P.; Meio, M.; NielsenSaines, K.; et al. Neurodevelopment of children exposed intra-uterus by Zika virus: A case series. PLoS ONE 2020, 15, e0229434. [CrossRef] [PubMed]

8. Van der Linden, V.; Pessoa, A.; Dobyns, W.; Barkovich, A.J.; van der Linden Júnior, H.; Filho, E.L.R.; Ribeiro, E.M.; de Carvalho Leal, M.; de Araújo Coimbra, P.P.; de Fátima Viana Vasco Aragão, M. Description of 13 infants born during October 2015-January 2016 with congenital Zika virus infection without microcephaly at birth-Brazil. Morb. Mortal. Wkly. Rep. 2016, 65, 1343-1348. [CrossRef]

9. Frota, L.; Sampaio, R.F.; Miranda, J.L.; Brasil, R.M.C.; Gontijo, A.P.B.; Mambrini, J.V.M.; Brandao, M.B.; Mancini, M.C. Children with congenital Zika syndrome: Symptoms, comorbidities and gross motor development at 24 months of age. Heliyon 2020, 6, e04130. [CrossRef]

10. Ventura, P.A.; Lage, M.-L.C.; de Carvalho, A.L.; Fernandes, A.S.; Taguchi, T.B.; Nascimento-Carvalho, C.M. Early Gross Motor Development Among Brazilian Children with Microcephaly Born Right After Zika Virus Infection Outbreak. J. Dev. Behav. Pediat. 2020, 41, 134-140. [CrossRef]

11. Lage, M.-L.C.; Carvalho, A.L.; Ventura, P.A.; Taguchi, T.B.; Fernandes, A.S.; Pinho, S.F.; Santos-Junior, O.T.; Ramos, C.L.; Nascimento-Carvalho, C.M. Clinical, Neuroimaging, and Neurophysiological Findings in Children with Microcephaly Related to Congenital Zika Virus Infection. Int. J. Env Res. Public Health 2019, 16, 309. [CrossRef] [PubMed]

12. Nielsen-Saines, K.; Brasil, P.; Kerin, T.; Vasconcelos, Z.; Gabaglia, C.R.; Damasceno, L.; Pone, M.; Abreu de Carvalho, L.M.; Pone, S.M.; Zin, A.A.; et al. Delayed childhood neurodevelopment and neurosensory alterations in the second year of life in a prospective cohort of ZIKV-exposed children. Nat. Med. 2019, 25, 1213-1217. [CrossRef]

13. Franca, T.L.B.; Medeiros, W.R.; Souza, N.L.; Longo, E.; Pereira, S.A.; Franca, T.B.O.; Sousa, K.G. Growth and Development of Children with Microcephaly Associated with Congenital Zika Virus Syndrome in Brazil. Int. J. Environ. Res. Public Health 2018, 15, 1990. [CrossRef]

14. Aguilar Ticona, J.P.; Nery, N., Jr.; Ladines-Lim, J.B.; Gambrah, C.; Sacramento, G.; de Paula Freitas, B.; Bouzon, J.; Oliveira-Filho, J.; Borja, A.; Adhikarla, H. Developmental outcomes in children exposed to Zika virus in utero from a Brazilian urban slum cohort study. PLoS Negl. Trop. Dis. 2021, 15, e0009162. [CrossRef]

15. Wheeler, A.C. Development of infants with congenital Zika syndrome: What do we know and what can we expect? Pediatrics 2018, 141, S154-S160. [CrossRef] [PubMed]

16. Mulkey, S.B. Head Circumference as a Measure of In Utero Zika Virus Exposure and Outcomes. JAMA Netw. Open 2020, 3 , e209461. [CrossRef] [PubMed]

17. Cranston, J.S.; Tiene, S.F.; Nielsen-Saines, K.; Vasconcelos, Z.; Pone, M.V.; Pone, S.; Zin, A.; Salles, T.S.; Pereira, J.P., Jr.; Orofino, D.; et al. Association Between Antenatal Exposure to Zika Virus and Anatomical and Neurodevelopmental Abnormalities in Children. JAMA Netw. Open 2020, 3, e209303. [CrossRef]

18. Cavalcante, T.B.; Ribeiro, M.R.C.; Sousa, P.D.S.; Costa, E.P.F.; Alves, M.; Simoes, V.M.F.; Batista, R.F.L.; Takahasi, E.H.M.; Amaral, G.A.; Khouri, R.; et al. Congenital Zika syndrome: Growth, clinical, and motor development outcomes up to 36 months of age and differences according to microcephaly at birth. Int. J. Infect. Dis. 2021, 105, 399-408. [CrossRef] [PubMed]

19. Soares de Souza, A.; Moraes Dias, C.; Braga, F.D.; Terzian, A.C.; Estofolete, C.F.; Oliani, A.H.; Oliveira, G.H.; Brandao de Mattos, C.C.; de Mattos, L.C.; Nogueira, M.L.; et al. Fetal Infection by Zika Virus in the Third Trimester: Report of 2 Cases. Clin. Infect. Dis. 2016, 63, 1622-1625. [CrossRef]

20. Wheeler, A.C.; Toth, D.; Ridenour, T.; Lima Nobrega, L.; Borba Firmino, R.; Marques da Silva, C.; Carvalho, P.; Marques, D.; Okoniewski, K.; Ventura, L.O.; et al. Developmental Outcomes among Young Children with Congenital Zika Syndrome in Brazil. JAMA Netw. Open 2020, 3, e204096. [CrossRef] [PubMed]

21. Cauchemez, S.; Besnard, M.; Bompard, P.; Dub, T.; Guillemette-Artur, P.; Eyrolle-Guignot, D.; Salje, H.; Van Kerkhove, M.D.; Abadie, V.; Garel, C.; et al. Association between Zika virus and microcephaly in French Polynesia, 2013-2015: A retrospective study. Lancet 2016, 387, 2125-2132. [CrossRef] 
22. Kleber de Oliveira, W.; Cortez-Escalante, J.; De Oliveira, W.T.; do Carmo, G.M.; Henriques, C.M.; Coelho, G.E.; Araujo de Franca, G.V. Increase in Reported Prevalence of Microcephaly in Infants Born to Women Living in Areas with Confirmed Zika Virus Transmission During the First Trimester of Pregnancy-Brazil, 2015. Mmwr. Morb. Mortal Wkly. Rep. 2016, 65, 242-247. [CrossRef] [PubMed]

23. Shapiro-Mendoza, C.K.; Rice, M.E.; Galang, R.R.; Fulton, A.C.; VanMaldeghem, K.; Prado, M.V.; Ellis, E.; Anesi, M.S.; Simeone, R.M.; Petersen, E.E.; et al. Pregnancy Outcomes After Maternal Zika Virus Infection During Pregnancy-U.S.; Territories, January 1, 2016-April 25, 2017. Mmwr. Morb. Mortal. Wkly. Rep. 2017, 66, 615-621. [CrossRef]

24. Lin, H.Z.; Tambyah, P.A.; Yong, E.L.; Biswas, A.; Chan, S.Y. A review of Zika virus infections in pregnancy and implications for antenatal care in Singapore. Singap. Med. J. 2017, 58, 171-178. [CrossRef]

25. Pomar, L.; Malinger, G.; Benoist, G.; Carles, G.; Ville, Y.; Rousset, D.; Hcini, N.; Pomar, C.; Jolivet, A.; Lambert, V. Association between Zika virus and fetopathy: A prospective cohort study in French Guiana. Ultrasound Obs. Gynecol. 2017, 49, 729-736. [CrossRef] [PubMed]

26. Setoh, Y.X.; Prow, N.A.; Peng, N.; Hugo, L.E.; Devine, G.; Hazlewood, J.E.; Suhrbier, A.; Khromykh, A.A. De Novo Generation and Characterization of New Zika Virus Isolate Using Sequence Data from a Microcephaly Case. mSphere 2017, 2, e00190-17. [CrossRef]

27. Stanelle-Bertram, S.; Walendy-Gnirss, K.; Speiseder, T.; Thiele, S.; Asante, I.A.; Dreier, C.; Kouassi, N.M.; Preuss, A.; Pilnitz-Stolze, G.; Muller, U.; et al. Male offspring born to mildly ZIKV-infected mice are at risk of developing neurocognitive disorders in adulthood. Nat. Microbiol. 2018, 3, 1161-1174. [CrossRef]

28. Yockey, L.J.; Varela, L.; Rakib, T.; Khoury-Hanold, W.; Fink, S.L.; Stutz, B.; Szigeti-Buck, K.; Van den Pol, A.; Lindenbach, B.D.; Horvath, T.L.; et al. Vaginal Exposure to Zika Virus during Pregnancy Leads to Fetal Brain Infection. Cell 2016, 166, 1247-1256.e4. [CrossRef]

29. Miner, J.J.; Cao, B.; Govero, J.; Smith, A.M.; Fernandez, E.; Cabrera, O.H.; Garber, C.; Noll, M.; Klein, R.S.; Noguchi, K.K.; et al. Zika Virus Infection during Pregnancy in Mice Causes Placental Damage and Fetal Demise. Cell 2016, 165, 1081-1091. [CrossRef]

30. Valentine, G.C.; Seferovic, M.D.; Fowler, S.W.; Major, A.M.; Gorchakov, R.; Berry, R.; Swennes, A.G.; Murray, K.O.; Suter, M.A.; Aagaard, K.M. Timing of gestational exposure to Zika virus is associated with postnatal growth restriction in a murine model. Am. J. Obs. Gynecol. 2018, 219, 403.e1-403.e9. [CrossRef] [PubMed]

31. Shao, Q.; Herrlinger, S.; Yang, S.L.; Lai, F.; Moore, J.M.; Brindley, M.A.; Chen, J.F. Zika virus infection disrupts neurovascular development and results in postnatal microcephaly with brain damage. Development 2016, 143, 4127-4136. [CrossRef]

32. Shao, Q.; Herrlinger, S.; Zhu, Y.N.; Yang, M.; Goodfellow, F.; Stice, S.L.; Qi, X.P.; Brindley, M.A.; Chen, J.F. The African Zika virus MR-766 is more virulent and causes more severe brain damage than current Asian lineage and dengue virus. Development 2017, 144, 4114-4124. [CrossRef] [PubMed]

33. Li, C.; Xu, D.; Ye, Q.; Hong, S.; Jiang, Y.; Liu, X.; Zhang, N.; Shi, L.; Qin, C.F.; Xu, Z. Zika Virus Disrupts Neural Progenitor Development and Leads to Microcephaly in Mice. Cell Stem Cell 2016, 19, 672. [CrossRef] [PubMed]

34. Yuan, L.; Huang, X.Y.; Liu, Z.Y.; Zhang, F.; Zhu, X.L.; Yu, J.Y.; Ji, X.; Xu, Y.P.; Li, G.; Li, C.; et al. A single mutation in the prM protein of Zika virus contributes to fetal microcephaly. Science 2017, 358, 933-936. [CrossRef] [PubMed]

35. Cui, L.; Zou, P.; Chen, E.; Yao, H.; Zheng, H.; Wang, Q.; Zhu, J.N.; Jiang, S.; Lu, L.; Zhang, J. Visual and Motor Deficits in Grown-up Mice with Congenital Zika Virus Infection. EBioMedicine 2017, 20, 193-201. [CrossRef]

36. Wu, K.Y.; Zuo, G.L.; Li, X.F.; Ye, Q.; Deng, Y.Q.; Huang, X.Y.; Cao, W.C.; Qin, C.F.; Luo, Z.G. Vertical transmission of Zika virus targeting the radial glial cells affects cortex development of offspring mice. Cell Res. 2016, 26, 645-654. [CrossRef] [PubMed]

37. Jaeger, A.S.; Murrieta, R.A.; Goren, L.R.; Crooks, C.M.; Moriarty, R.V.; Weiler, A.M.; Rybarczyk, S.; Semler, M.R.; Huffman, C.; Mejia, A.; et al. Zika viruses of African and Asian lineages cause fetal harm in a mouse model of vertical transmission. PLoS Negl. Trop. Dis. 2019, 13, e0007343. [CrossRef]

38. Lanciotti, R.S.; Lambert, A.J.; Holodniy, M.; Saavedra, S.; Signor Ldel, C. Phylogeny of Zika Virus in Western Hemisphere, 2015. Emerg. Infect. Dis. 2016, 22, 933-935. [CrossRef]

39. Duggal, N.K.; McDonald, E.M.; Weger-Lucarelli, J.; Hawks, S.A.; Ritter, J.M.; Romo, H.; Ebel, G.D.; Brault, A.C. Mutations present in a low-passage Zika virus isolate result in attenuated pathogenesis in mice. Virology 2019, 530, 19-26. [CrossRef]

40. Nakayama, E.; Kato, F.; Tajima, S.; Ogawa, S.; Yan, K.; Takahashi, K.; Sato, Y.; Suzuki, T.; Kawai, Y.; Inagaki, T.; et al. Neuroinvasiveness of the MR766 strain of Zika virus in IFNAR-/- mice maps to prM residues conserved amongst African genotype viruses. PLoS Pathog. 2021, 17, e1009788. [CrossRef]

41. Setoh, Y.X.; Peng, N.Y.; Nakayama, E.; Amarilla, A.A.; Prow, N.A.; Suhrbier, A.; Khromykh, A.A. Fetal Brain Infection Is Not a Unique Characteristic of Brazilian Zika Viruses. Viruses 2018, 10, 541. [CrossRef]

42. Prow, N.A.; Liu, L.; Nakayama, E.; Cooper, T.H.; Yan, K.; Eldi, P.; Hazlewood, J.E.; Tang, B.; Le, T.T.; Setoh, Y.X.; et al. A vaccinia-based single vector construct multi-pathogen vaccine protects against both Zika and chikungunya viruses. Nat. Commun. 2018, 9, 1230. [CrossRef]

43. Kawai, Y.; Nakayama, E.; Takahashi, K.; Taniguchi, S.; Shibasaki, K.I.; Kato, F.; Maeki, T.; Suzuki, T.; Tajima, S.; Saijo, M.; et al. Increased growth ability and pathogenicity of American- and Pacific-subtype Zika virus (ZIKV) strains compared with a Southeast Asian-subtype ZIKV strain. PLoS Negl. Trop. Dis. 2019, 13, e0007387. [CrossRef] [PubMed] 
44. Kato, F.; Tajima, S.; Nakayama, E.; Kawai, Y.; Taniguchi, S.; Shibasaki, K.; Taira, M.; Maeki, T.; Lim, C.K.; Takasaki, T.; et al. Characterization of large and small-plaque variants in the Zika virus clinical isolate ZIKV/Hu/S36/Chiba/2016. Sci. Rep. 2017, 7, 16160. [CrossRef] [PubMed]

45. Hobson-Peters, J.; Harrison, J.J.; Watterson, D.; Hazlewood, J.E.; Vet, L.J.; Newton, N.D.; Warrilow, D.; Colmant, A.M.G.; Taylor, C.; Huang, B.; et al. A recombinant platform for flavivirus vaccines and diagnostics using chimeras of a new insect-specific virus. Sci. Transl. Med. 2019, 11. [CrossRef]

46. Hazlewood, J.E.; Rawle, D.J.; Tang, B.; Yan, K.; Vet, L.J.; Nakayama, E.; Hobson-Peters, J.; Hall, R.A.; Suhrbier, A. A Zika Vaccine Generated Using the Chimeric Insect-Specific Binjari Virus Platform Protects against Fetal Brain Infection in Pregnant Mice. Vaccines 2020, 8, 496. [CrossRef] [PubMed]

47. Lanciotti, R.S.; Kosoy, O.L.; Laven, J.J.; Velez, J.O.; Lambert, A.J.; Johnson, A.J.; Stanfield, S.M.; Duffy, M.R. Genetic and serologic properties of Zika virus associated with an epidemic, Yap State, Micronesia, 2007. Emerg. Infect. Dis. 2008, 14, 1232-1239. [CrossRef] [PubMed]

48. Gardner, J.; Anraku, I.; Le, T.T.; Larcher, T.; Major, L.; Roques, P.; Schroder, W.A.; Higgs, S.; Suhrbier, A. Chikungunya virus arthritis in adult wild-type mice. J. Virol. 2010, 84, 8021-8032. [CrossRef] [PubMed]

49. Schroder, W.A.; Le, T.T.; Major, L.; Street, S.; Gardner, J.; Lambley, E.; Markey, K.; MacDonald, K.P.; Fish, R.J.; Thomas, R.; et al. A physiological function of inflammation-associated SerpinB2 is regulation of adaptive immunity. J. Immunol. 2010, 184, 2663-2670. [CrossRef]

50. Rogers, D.C.; Fisher, E.M.; Brown, S.D.; Peters, J.; Hunter, A.J.; Martin, J.E. Behavioral and functional analysis of mouse phenotype: SHIRPA, a proposed protocol for comprehensive phenotype assessment. Mamm. Genome: Off. J. Int. Mamm. Genome Soc. 1997, 8, 711-713. [CrossRef]

51. Martins, Y.C.; Werneck, G.L.; Carvalho, L.J.; Silva, B.P.; Andrade, B.G.; Souza, T.M.; Souza, D.O.; Daniel-Ribeiro, C.T. Algorithms to predict cerebral malaria in murine models using the SHIRPA protocol. Malar. J. 2010, 9, 1-13. [CrossRef]

52. Romeo, R.D.; Mueller, A.; Sisti, H.M.; Ogawa, S.; McEwen, B.S.; Brake, W.G. Anxiety and fear behaviors in adult male and female C57BL/ 6 mice are modulated by maternal separation. Horm. Behav. 2003, 43, 561-567. [CrossRef]

53. Parfitt, D.B.; Levin, J.K.; Saltstein, K.P.; Klayman, A.S.; Greer, L.M.; Helmreich, D.L. Differential early rearing environments can accentuate or attenuate the responses to stress in male C57BL/6 mice. Brain Res. 2004, 1016, 111-118. [CrossRef]

54. Lackner, P.; Beer, R.; Heussler, V.; Goebel, G.; Rudzki, D.; Helbok, R.; Tannich, E.; Schmutzhard, E. Behavioural and histopathological alterations in mice with cerebral malaria. Neuropathol. Appl. Neurobiol. 2006, 32, 177-188. [CrossRef]

55. Lacerda-Queiroz, N.; Rodrigues, D.H.; Vilela, M.C.; Miranda, A.S.; Amaral, D.C.; Camargos, E.R.; Carvalho, L.J.; Howe, C.L.; Teixeira, M.M.; Teixeira, A.L. Inflammatory changes in the central nervous system are associated with behavioral impairment in Plasmodium berghei (strain ANKA)-infected mice. Exp. Parasitol. 2010, 125, 271-278. [CrossRef] [PubMed]

56. Maeki, T.; Tajima, S.; Ikeda, M.; Kato, F.; Taniguchi, S.; Nakayama, E.; Takasaki, T.; Lim, C.K.; Saijo, M. Analysis of cross-reactivity between flaviviruses with sera of patients with Japanese encephalitis showed the importance of neutralization tests for the diagnosis of Japanese encephalitis. J. Infect. Chemother. Off. J. Jpn. Soc. Chemother. 2019, 25, 786-790. [CrossRef]

57. Tajima, S.; Yagasaki, K.; Kotaki, A.; Tomikawa, T.; Nakayama, E.; Moi, M.L.; Lim, C.K.; Saijo, M.; Kurane, I.; Takasaki, T. In vitro growth, pathogenicity and serological characteristics of the Japanese encephalitis virus genotype V Muar strain. J. Gen. Virol. 2015, 96, 2661-2669. [CrossRef] [PubMed]

58. Mu, J.; Slevin, J.C.; Qu, D.; McCormick, S.; Adamson, S.L. In vivo quantification of embryonic and placental growth during gestation in mice using micro-ultrasound. Reprod. Biol. Endocrinol. RbE 2008, 6, 34. [CrossRef]

59. de Paula Freitas, B.; de Oliveira Dias, J.R.; Prazeres, J.; Sacramento, G.A.; Ko, A.I.; Maia, M.; Belfort, R. Ocular findings in infants with microcephaly associated with presumed Zika virus congenital infection in Salvador, Brazil. Jama Ophthalmol. 2016, 134, 529-535. [CrossRef]

60. Guevara, J.G.; Agarwal-Sinha, S. Ocular abnormalities in congenital Zika syndrome: A case report, and review of the literature. J. Med. Case Rep. 2018, 12, 1-5. [CrossRef] [PubMed]

61. Sousa, A.Q.; Cavalcante, D.I.M.; Franco, L.M.; Araujo, F.M.C.; Sousa, E.T.; Valenca-Junior, J.T.; Rolim, D.B.; Melo, M.E.L.; Sindeaux, P.D.T.; Araujo, M.T.F.; et al. Postmortem Findings for 7 Neonates with Congenital Zika Virus Infection. Emerg. Infect. Dis. 2017, 23, 1164-1167. [CrossRef] [PubMed]

62. Ximenes, A.; Pires, P.; Werner, H.; Jungmann, P.M.; Rolim Filho, E.L.; Andrade, E.P.; Lemos, R.S.; Peixoto, A.B.; Zare Mehrjardi, M.; Tonni, G.; et al. Neuroimaging findings using transfontanellar ultrasound in newborns with microcephaly: A possible association with congenital Zika virus infection. J. Matern. Fetal. Neonatal. Med. 2019, 32, 493-501. [CrossRef] [PubMed]

63. Sones, J.L.; Davisson, R.L. Preeclampsia, of mice and women. Physiol. Genom. 2016, 48, 565-572. [CrossRef] [PubMed]

64. Szaba, F.M.; Tighe, M.; Kummer, L.W.; Lanzer, K.G.; Ward, J.M.; Lanthier, P.; Kim, I.J.; Kuki, A.; Blackman, M.A.; Thomas, S.J.; et al. Zika virus infection in immunocompetent pregnant mice causes fetal damage and placental pathology in the absence of fetal infection. PLoS Pathog. 2018, 14, e1006994. [CrossRef] [PubMed]

65. Ander, S.E.; Diamond, M.S.; Coyne, C.B. Immune responses at the maternal-fetal interface. Sci. Immunol. 2019, 4, eaat6114. [CrossRef] [PubMed]

66. Malassiné, A.; Frendo, J.L.; Evain-Brion, D. A comparison of placental development and endocrine functions between the human and mouse model. Hum. Reprod. Update 2003, 9, 531-539. [CrossRef] [PubMed] 
67. Lee, P.A.; Chernausek, S.D.; Hokken-Koelega, A.C.; Czernichow, P. International Small for Gestational Age Advisory Board consensus development conference statement: Management of short children born small for gestational age, April 24-October 1, 2001. Pediatrics 2003, 111, 1253-1261. [CrossRef]

68. Shields, B.; Wacogne, I.; Wright, C.M. Weight faltering and failure to thrive in infancy and early childhood. BMJ 2012, 345 , e5931. [CrossRef]

69. Ashwal, S.; Michelson, D.; Plawner, L.; Dobyns, W.B. Quality Standards Subcommittee of the American Academy of, N.; the Practice Committee of the Child Neurology, S. Practice parameter: Evaluation of the child with microcephaly (an evidence-based review): Report of the Quality Standards Subcommittee of the American Academy of Neurology and the Practice Committee of the Child Neurology Society. Neurology 2009, 73, 887-897. [CrossRef]

70. von der Hagen, M.; Pivarcsi, M.; Liebe, J.; von Bernuth, H.; Didonato, N.; Hennermann, J.B.; Buhrer, C.; Wieczorek, D.; Kaindl, A.M. Diagnostic approach to microcephaly in childhood: A two-center study and review of the literature. Dev. Med. Child. Neurol. 2014, 56, 732-741. [CrossRef]

71. Panchaud, A.; Stojanov, M.; Ammerdorffer, A.; Vouga, M.; Baud, D. Emerging Role of Zika Virus in Adverse Fetal and Neonatal Outcomes. Clin. Microbiol. Rev. 2016, 29, 659-694. [CrossRef]

72. Shan, C.; Xie, X.; Luo, H.; Muruato, A.E.; Liu, Y.; Wakamiya, M.; La, J.H.; Chung, J.M.; Weaver, S.C.; Wang, T.; et al. Maternal vaccination and protective immunity against Zika virus vertical transmission. Nat. Commun. 2019, 10, 5677. [CrossRef] [PubMed]

73. Aubry, F.; Jacobs, S.; Darmuzey, M.; Lequime, S.; Delang, L.; Fontaine, A.; Jupatanakul, N.; Miot, E.F.; Dabo, S.; Manet, C.; et al. Recent African strains of Zika virus display higher transmissibility and fetal pathogenicity than Asian strains. Nat. Commun. 2021, 12, 916. [CrossRef] [PubMed]

74. Cugola, F.R.; Fernandes, I.R.; Russo, F.B.; Freitas, B.C.; Dias, J.L.; Guimaraes, K.P.; Benazzato, C.; Almeida, N.; Pignatari, G.C.; Romero, S.; et al. The Brazilian Zika virus strain causes birth defects in experimental models. Nature 2016, 534, 267-271. [CrossRef]

75. Paul, A.M.; Acharya, D.; Neupane, B.; Thompson, E.A.; Gonzalez-Fernandez, G.; Copeland, K.M.; Garrett, M.; Liu, H.; Lopez, M.E.; de Cruz, M.; et al. Congenital Zika Virus Infection in Immunocompetent Mice Causes Postnatal Growth Impediment and Neurobehavioral Deficits. Front. Microbiol. 2018, 9, 2028. [CrossRef] [PubMed]

76. Julander, J.G.; Siddharthan, V.; Park, A.H.; Preston, E.; Mathur, P.; Bertolio, M.; Wang, H.; Zukor, K.; Van Wettere, A.J.; Sinex, D.G.; et al. Consequences of in utero exposure to Zika virus in offspring of AG129 mice. Sci. Rep. 2018, 8, 9384. [CrossRef]

77. Swann, J.B.; Hayakawa, Y.; Zerafa, N.; Sheehan, K.C.; Scott, B.; Schreiber, R.D.; Hertzog, P.; Smyth, M.J. Type I IFN contributes to NK cell homeostasis, activation, and antitumor function. J. Immun. 2007, 178, 7540-7549. [CrossRef] [PubMed] 